\title{
Trauma Surgery $\&$ Acute Care Open \\ Effect of the COVID-19 pandemic on the ability of level 1 trauma centers to meet American College of Surgeons research requirements
}

\author{
Robert M Madayag, ${ }^{1}$ Erica Sercy $0{ }^{2}{ }^{2}$ Gina M Berg, ${ }^{3}$ Kaysie L Banton, ${ }^{4}$ \\ Matthew Carrick, ${ }^{5}$ Mark Lieser, ${ }_{1}^{6}$ Allen Tanner, ${ }^{7}$ David Bar-Or ${ }^{2}$
}

'Trauma Services Department, St Anthony Hospital \& Medical Campus, Lakewood, Colorado, USA

${ }^{2}$ Trauma Research Department, Swedish Medical Center Englewood, Colorado, USA ${ }^{3}$ Trauma Services Department, Wesley Medical Center, Wichita, Kansas, USA

${ }^{4}$ Trauma Services Department, Swedish Medical Center, Englewood, Colorado, USA ${ }^{5}$ Trauma Services Department, Medical Center of Plano, Plano, Texas, USA

${ }^{6}$ Trauma Services Department, Research Medical Center, Kansas City, Missouri, USA ${ }^{7}$ Trauma Services Department, Penrose Hospital, Colorado Springs, Colorado, USA

Correspondence to Dr David Bar-Or; davidbme49@ gmail.com

Received 25 January 2021 Revised 9 February 2021 Accepted 14 February 2021 (c) Author(s) (or their employer(s)) 2021. Re-use permitted under CC BY-NC. No commercial re-use. See rights and permissions. Published by BMJ.

\section{To cite: Madayag RM} Sercy E, Berg GM, et al. Trauma Surg Acute Care Open 2021:6:e000692.

\section{ABSTRACT}

Introduction The COVID-19 pandemic has had major effects on hospitals' ability to perform scientific research while providing patient care and minimizing virus exposure and spread. Many non-COVID-19 research has been halted, and funding has been diverted to COVID-19 research and away from other areas.

Methods A 28-question survey was administered to all level 1 trauma centers in the USA that included questions about how the pandemic affected the trauma centers' ability to fulfill the volume and research requirements of level 1 verification by the American College of Surgeons (ACS).

Results The survey had a $29 \%$ response rate (40/137 successful invitations). Over half of respondents $(52 \%)$ reported reduced trauma admissions during the pandemic, and $7 \%$ reported that their admissions dropped below the volume required for level 1 verification. Many centers diverted resources from research during the pandemic (44\%), halted ongoing consenting studies (33\%), and had difficulty fulfilling research requirements because of competing clinical priorities (40\%).

Discussion Results of this study show a need for flexibility in the ACS verification process during the COVID-19 pandemic, potentially including reduction of the required admissions and/or research publication volumes.

Level of evidence Level IV, cross-sectional study.

\section{INTRODUCTION}

The wide-ranging effects of the COVID-19 pandemic have included major impacts on scientific research. This is especially true of research conducted at facilities that also provide patient care. To reduce potential exposure to and spread of the virus, as well as ensure adequate resources are directed towards patient care, many facilities have halted all research not directly related to COVID-19 and moved all non-essential research and activities to remote work. ${ }^{1-5}$ Time-sensitive biomedical, laboratory, and animal research has been particularly affected, ${ }^{1}$ and residents have reported being unable to perform ongoing research needed to complete their programs or have been reassigned from their normal rotations to COVID-19 patient care. ${ }^{6-8}$ Funding from major sources such as the National Institutes of Health has been diverted to COVID-19 research and away from other areas. ${ }^{2} 3$ Most, if not all, major scientific conferences have been moved to a virtual format. ${ }^{9-11}$ To attempt to minimize long-term setbacks in non-COVID-19 research, flexibility has often been allowed by academic and funding organizations in areas such as grant spending and project timelines.

Facilities designated as level 1 trauma centers by the American College of Surgeons (ACS) are comprehensive regional resources that provide the highest level of specialized trauma care. ${ }^{12-14}$ Verification as an adult level 1 trauma center has requirements that include a volume threshold $(\geq 1200$ adult trauma admissions, or $\geq 240$ admissions with Injury Severity Score $>15$, per year), as well as an active and productive research program. ${ }^{15}$ The research program requirements include either 20 publications per 3-year review period or a combination of 10 publications and participation in research activities such as lectures at national conferences and leadership in major trauma organizations. ${ }^{15}$ In response to the COVID-19 pandemic, the ACS has postponed all verification site visits scheduled for March to December 2020 and has extended all verifications expiring in 2020-2023 for an additional 1 year; centers with expiration dates in 2021-2023 must also adjust their 3-year reporting period to reflect the new verification date. ${ }^{16}$ This study aimed to determine the effect of the pandemic on trauma centers' ability to fulfill ACS level 1 admission and research requirements by administering a survey to all ACS-verified level 1 trauma centers nationwide.

\section{METHODS}

A 28-question survey was designed with input from the trauma medical directors and clinical research coordinators at six level 1 trauma centers in four states. The survey was organized into five sections that explored many facets of the centers' research programs; one of these sections queried specifically about the effect of the COVID-19 pandemic on ongoing research activities and trauma admission volumes (the survey questions described in this article are included as online supplemental figure 1). The preferred contact at each trauma center was the trauma program director or trauma program manager; if this position did not exist or no email contact information was available, the survey was instead sent to the trauma medical director. The ACS website was used to obtain the current list of all ACS-verified level 1 trauma centers, which included 175 facilities as of November 1, 2020. Websites and phone numbers for the trauma centers were 
Table 1 ACS-verified level 1 trauma centers and the effect of COVID-19 on research activities

\begin{tabular}{|c|c|c|c|c|}
\hline & $\begin{array}{l}\text { All } \\
n=40\end{array}$ & $\begin{array}{l}\text { Academic } \\
\mathrm{n}=34(85 \%)\end{array}$ & $\begin{array}{l}\text { Non-academic } \\
\mathrm{n}=6(15 \%)\end{array}$ & Total responses \\
\hline \multicolumn{5}{|l|}{ Facility characteristics } \\
\hline Type of facility & & & & 40 \\
\hline Academic & $34(85 \%)$ & - & - & \\
\hline Non-academic & $6(15 \%)$ & - & - & \\
\hline Profit status & & & & 39 \\
\hline Non-profit & $32(82 \%)$ & $29(88 \%)$ & $3(50 \%)$ & \\
\hline For profit & $2(5 \%)$ & $0(0 \%)$ & $2(33 \%)$ & \\
\hline Government & $5(13 \%)$ & $4(12 \%)$ & $1(17 \%)$ & \\
\hline Part of a hospital system & $34(85 \%)$ & $28(82 \%)$ & $6(100 \%)$ & 40 \\
\hline Total licensed beds (median (IQR), range) & 509 (400-700), 249-1000 & 545 (400-710), 249-1000 & $440(330-600), 250-800$ & 38 \\
\hline $\begin{array}{l}\text { Approximate adult trauma admissions in the past } \\
12 \text { months (median (IQR), range) }\end{array}$ & $2300(1500-3000), 1200-4800$ & 2190 (1450-3100), 1200-4800 & $2450(1500-3000), 1500-3100$ & 38 \\
\hline $\begin{array}{l}\text { Years of ACS level } 1 \text { verification (median (IQR), } \\
\text { range) }\end{array}$ & $20(7-28), 1-36$ & 20 (7-28), 1-36 & 14 (4-28), 3-30 & 40 \\
\hline \multicolumn{5}{|l|}{ Effects of the COVID-19 pandemic } \\
\hline $\begin{array}{l}\text { Trauma service admissions reduced during } \\
\text { COVID-19 }\end{array}$ & $14(52 \%)$ & $11(52 \%)$ & $3(50 \%)$ & 27 \\
\hline $\begin{array}{l}\text { Admission reductions to levels below those } \\
\text { required for level } 1 \text { verification }\end{array}$ & $2(7 \%)$ & $2(10 \%)$ & $0(0 \%)$ & 27 \\
\hline $\begin{array}{l}\text { Scheduled for review during March to December } \\
2020\end{array}$ & $14(52 \%)$ & $12(57 \%)$ & $2(33 \%)$ & 27 \\
\hline $\begin{array}{l}\text { Resource diversion from research during } \\
\text { COVID-19 }\end{array}$ & $12(44 \%)$ & $9(43 \%)$ & $3(50 \%)$ & 27 \\
\hline Consenting studies postponed during COVID-19 & $10(37 \%)$ & $7(33 \%)$ & $3(50 \%)$ & 27 \\
\hline $\begin{array}{l}\text { Competing priorities during COVID- } 19 \text { have made } \\
\text { it difficult to fulfill level } 1 \text { requirements }\end{array}$ & $10(40 \%)$ & $8(42 \%)$ & $2(33 \%)$ & 25 \\
\hline
\end{tabular}

ACS, American College of Surgeons.

used to obtain contact email addresses. Survey administration was conducted via SurveyMonkey and included one invitation email and four reminder emails sent once a week to all nonrespondents during the period November 12, 2020 to December 10, 2020. All responses were collected anonymously and were not able to be matched back to the respondent. The study was deemed not human subjects research by the Institutional Review Board at the principal investigator's institution.

Data were exported from SurveyMonkey and analyzed using SAS V.9.4. Descriptive statistics are reported as $\mathrm{n}(\%)$ or median (IQR) and are shown for the overall study population, as well as the subgroups of academic and non-academic centers.

\section{RESULTS}

Email contact information was able to be obtained for 152 of the level 1 trauma centers. Of the 152 survey invitations sent out, 14 bounced, and one participant opted out. The total number of successful invitations issued was therefore 137 . Forty total responses were received ( 25 complete, 15 partial) for a response rate of $29 \%$, representing $23 \%$ of all level 1 trauma centers nationwide (40/175). The survey section pertaining to the effect of COVID-19 on research received 27 responses for a response rate of $20 \%$ to this section, or an overall representation of $15 \%$ of all level 1 trauma centers. Eighty-five percent $(n=34)$ of the responses were from academic centers, 15\% $(n=6)$ were from non-academic centers, and most were non-profit $(82 \%, n=32)$ (table 1). The responding centers had a median of 509 licensed beds, 2300 adult trauma admissions in the previous 12 months, and had been ACS verified for a median of 20 years.
Over half of level 1 trauma centers reported reduced admissions during the pandemic period $(52 \%, \mathrm{n}=14)$. Two centers (7\%, both academic) reported that these drops will likely reduce their admission volumes to levels below those required for ACS level 1 verification. Approximately half of centers (52\%, $\mathrm{n}=14$ ) were scheduled for ACS re-review during the period March to December 2020 (57\%, n=12 academic compared with $33 \%, n=2$ non-academic). Almost half of centers (44\%, $\mathrm{n}=12$ ) reported diverting resources away from research during the pandemic $(43 \%, \mathrm{n}=9$ academic compared with $50 \%, \mathrm{n}=3$ non-academic), and over a third $(37 \%, \mathrm{n}=10)$ postponed or halted ongoing consenting studies during the pandemic (33\%, $\mathrm{n}=7$ academic compared with $50 \%, \mathrm{n}=3$ non-academic). Forty percent of survey respondents $(n=10)$ reported that competing hospital priorities during the pandemic have made it difficult to fulfill ACS level 1 trauma center requirements.

\section{DISCUSSION}

Recent studies and personal accounts have shown that the COVID-19 pandemic has forced halting of non-COVID-19 research activities and has diverted resources towards patient care and away from scientific research. ${ }^{1-617}$ This study examined the effect of the COVID-19 pandemic on the research activities of level 1 trauma centers and their ability to continue to meet ACS level 1 verification requirements during the pandemic.

Survey results showed that during the COVID-19 pandemic, level 1 trauma centers have experienced challenges in meeting both the volume and research program requirements of ACS verification. Two academic trauma centers reported that the 
reductions they experienced in admission volumes will likely drop them below the volume required for level 1 verification. Many centers reported diverting resources from research (44\%) or postponing ongoing consenting studies (37\%), and 40\% reported that competing priorities during the pandemic have made it difficult to fulfill the level 1 research requirements. Over half of the responding centers (52\%) were scheduled for reverification during the pandemic period of March to December 2020 and thus have had their reviews postponed.

\section{Limitations}

As with all surveys, this study was subject to potential participation bias. Academic trauma centers were over-represented among respondents: a 2008 study estimated that $\sim 66 \%$ of ACS-verified level 1 centers were associated with a university, ${ }^{13}$ but $85 \%$ of respondents to this survey classified themselves as academic centers. The respondents here reported comparable bed size and hospital system participation as the centers described a previous inventory of all level 1 trauma centers nationwide, ${ }^{18}$ although the current study showed under-representation of public/ government centers ( $15 \%$ here, $34 \%$ in the previous study) and over-representation of private non-profit centers $(80 \%$ here, $63 \%$ in the previous study). Additionally, assuming approximate equal distribution of reporting periods, it would be expected that $28 \%$ of level 1 trauma centers would have been scheduled for review during the pandemic period of March to December 2020; however, $52 \%$ of centers that responded to this survey were scheduled for review during this period. It is possible that these centers were experiencing a high number of research setbacks during this period that directly affected ACS verification and were more likely to respond to this survey.

Because the section of questions pertaining to the effect of COVID-19 on research was near the end of the larger survey on research programs in general, this section had a lower response rate than the overall survey $(\mathrm{n}=40$ completed at least one survey section compared with $\mathrm{n}=27$ completed the COVID-19-related section). Despite these limitations, this study offers insights into how resources were diverted from research during the COVID-19 pandemic among the level 1 centers that did respond.

\section{CONCLUSIONS}

In response to research challenges during the pandemic, many academic and funding organizations have introduced flexibility, including extending research deadlines and relaxing grantspending requirements. ${ }^{5}$ The ACS has delayed site visits and altered review periods during this time, but many centers still face an inability to meet ACS requirements because of volume shortfalls or diversion of research resources. Potential solutions include reduced trauma admission volume and publication requirements for ACS verification during the months or years that the COVID-19 pandemic has dramatically affected the facilities' ability to conduct research, as well as a longer review period or considering COVID-19-related articles for the fulfillment of publication requirements.

Contributors RMM conceived the study, assisted in study and survey design, participated in data interpretation, provided critical article revisions, and approved the final article. ES assisted in study and survey design, conducted literature searches, data collection, data analyses, and data interpretation, wrote the first draft of the article, provided critical article revisions, and approved the final article. $\mathrm{GMB}, \mathrm{KLB}, \mathrm{MC}, \mathrm{ML}$, and AT participated in survey design and data interpretation, provided critical article revisions, and approved the final article. DB-O supervised the study, participated in survey design and data interpretation, provided critical article revisions, and approved the final article.

Funding The authors have not declared a specific grant for this research from any funding agency in the public, commercial or not-for-profit sectors.

Competing interests None declared.

Patient consent for publication Not required.

Ethics approval This study was reviewed by the Catholic Health Initiatives Institute for Research and Innovation Institutional Review Board (CHIRB) (study number 1653782-1), and was determined to not require further IRB review or approval, as it did not meet the criteria for human subject research under the purview of the IRB according to federal regulations.

Provenance and peer review Not commissioned; externally peer reviewed.

Open access This is an open access article distributed in accordance with the Creative Commons Attribution Non Commercial (CC BY-NC 4.0) license, which permits others to distribute, remix, adapt, build upon this work non-commercially, and license their derivative works on different terms, provided the original work is properly cited, appropriate credit is given, any changes made indicated, and the use is non-commercial. See: http://creativecommons.org/licenses/by-nc/4.0/.

\section{ORCID iD}

Erica Sercy http://orcid.org/0000-0002-7975-8601

\section{REFERENCES}

1 Omary MB, Eswaraka J, Kimball SD, Moghe PV, Panettieri RA, Scotto KW. The COVID-19 pandemic and research shutdown: staying safe and productive. J Clin Invest 2020;130:2745-8.

2 Yanow SK, Good MF. Nonessential research in the new normal: the impact of COVID-19. Am J Trop Med Hyg 2020;102:1164-5.

3 Weiner DL, Balasubramaniam V, Shah SI, Javier JR, . Pediatric Policy Council. COVID-19 impact on research, lessons learned from COVID-19 research, implications for pediatric research. Pediatr Res 2020;88:148-50.

4 Ousset PJ, Vellas B. Viewpoint: impact of the Covid-19 outbreak on the clinical and research activities of memory clinics: an Alzheimer's disease center facing the Covid-19 crisis. J Prev Alzheimers Dis 2020;7:197-8.

5 Safeguard research in the time of COVID-19. Nat Med 2020;26:443.

6 Clark VE. Editorial. impact of COVID-19 on neurosurgery resident research training. J Neurosurg 2020;133:12-13.

7 An TW, Henry JK, Igboechi O, Wang P, Yerrapragada A, Lin CA, Paiement GD. How are orthopaedic surgery residencies responding to the COVID-19 pandemic? an assessment of resident experiences in cities of major virus outbreak. J Am Acad Orthop Surg 2020;28:E679-85.

8 Juprasert JM, Gray KD, Moore MD, Obeid L, Peters AW, Fehling D, Fahey TJ, Yeo $\mathrm{HL}$. Restructuring of a general surgery residency program in an epicenter of the coronavirus disease 2019 pandemic: lessons from New York City. JAMA Surg 2020;155:870-5.

9 Houston S. Lessons of COVID-19: virtual conferences. J Exp Med 2020;217

10 Jarvis T, Weiman S, Johnson D. Reimagining scientific conferences during the pandemic and beyond. Sci. Adv. 2020;6:eabe5815-31.

11 Fulcher MR, Bolton ML, Millican MD, Michalska-Smith MJ, Dundore-Arias JP, Handelsman J, Klassen JL, Milligan-Myhre KC, Shade A, Wolfe BE, et al. Broadening participation in scientific conferences during the era of social distancing. Trends Microbiol 2020:28:949-52.

12 Shafi S, Barnes S, Ahn C, Hemilla MR, Cryer HG, Nathens A, Neal M, Fildes J. Characteristics of ACS-verified level I and level II trauma centers: a study linking trauma center verification review data and the National trauma data bank of the American College of surgeons Committee on trauma. J Trauma Acute Care Surg 2016:81:735-42.

13 Ziran BH, Barrette-Grischow M-K, Hileman B. United States level I trauma centers are not created equal - a concern for patient safety? Patient Saf Surg 2008:2:18.

14 Kim Y-J, Xiao Y, Mackenzie CF, Gardner SD. Availability of trauma specialists in level and II trauma centers: a national survey. J Trauma 2007;63:676-83.

15 American College of Surgeons. Resources for optimal care of the injured patients. https://www.facs.org/Quality-Programs/Trauma/TQP/center-programs/VRC/resources (16 Dec 2020).

16 American College of Surgeons. Clarification of the verification extension and site visit postponement. https://www.facs.org/quality-programs/trauma/tqp/center-programs/ vrc/postponement (16 Dec 2020)

17 Haleem A, Javaid M, Vaishya R, Deshmukh SG. Areas of academic research with the impact of COVID-19. Am J Emerg Med 2020;38:1524-6.

18 MacKenzie EJ, Hoyt DB, Sacra JC, Jurkovich GJ, Carlini AR, Teitelbaum SD, Teter H. National inventory of hospital trauma centers. JAMA 2003;289:1515-22. 